\title{
An explorative study on factors influencing the career success of management employees
}

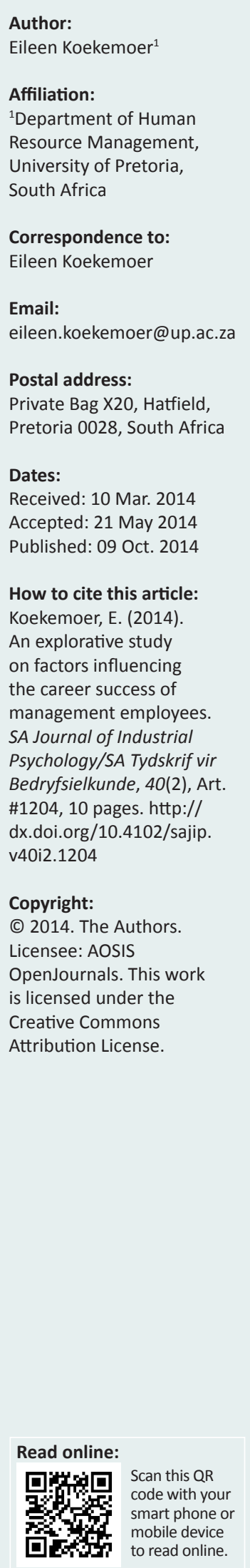

Orientation: South African organisations are increasingly recognising the importance of attracting, developing and retaining top talent, especially management employees.

Research purpose: In an attempt to help organisations with retaining talent, this study focused on career success and identified specific factors that influence the career success of managers in the South African work environment.

Motivation for the study: Organisations need to establish favourable organisational conditions and human resource practices to retain their management employees. By identifying influential factors for the career success of managers, this research may help organisations to focus more accurately on their retention strategies for management employees.

Research approach, design and method: The present study used a qualitative research design that followed an exploratory approach. A non-probability purposive sample of 24 senior management employees was selected from two financial institutions in South Africa. Qualitative data was collected by means of semi-structured interviews and the verbatim transcriptions were analysed by content analysis.

Main findings: Managers identified various factors that impact on their career success. One can distinguish 'external' factors (e.g. political and economic climate and business environment) from 'internal' factors (e.g. individuals' personal attributes, skills and education).

Practical/managerial implications: Individuals should focus on the internal contributing factors, whilst organisations should manage the external contributing factors more effectively.

Contribution/value-add: Specific South African factors that influence the career success of managers should be included in future retention strategies. From the findings it is suggested that both the individuals and organisations can implement strategies to ensure career success and thereby help retain the top talent in organisations.

\section{Introduction}

Businesses constantly seek improved ways of achieving a competitive advantage in today's business environment. In this sense the knowledge and expertise of employees should be regarded as a critical strategic resource (Martins \& Martins, 2011). It is thus imperative to retain those key employees who hold positions that are critical for the success of the organisation (e.g. those in managerial positions). However, the situation is that South African businesses are experiencing a general skills crisis by losing top talent or the knowledge workforce (also referred to as the 'brain drain') (Du Preez, 2002). Thus, major concerns are being raised about future career prospects for top talent in South African businesses. The government has intervened by imposing an array of mandatory regulations. However, businesses perceive some of these regulations (e.g. Black Economic Empowerment [BEE] and employment equity legislation) as impacting negatively on South African businesses in terms of global competitiveness, productivity and human development (Kruger, 2011; also Kerr-Phillips \& Thomas, 2009). Therefore, retaining the talent is a macro-challenge for South African society and a micro-challenge for South African organisations, especially regarding management positions.

These retention challenges in the contemporary world of work have led to a renewed interest in career development and factors that influence individuals' commitment to an organisation (Coetzee \& Gunz, 2012). However, career development, professional issues and organisational career interventions in the South African work environment seem to be under-researched (Coetzee \& Gunz, 2012). There is a need for research that goes beyond merely supporting career development of individuals, for research involving the effect of employee development constructs on success in careers of workers (Maurer \& Chapman, 2013).

Organisations should try to establish favourable organisational conditions and human resource practices that will address the varying career needs of a diverse workforce (Coetzee 
\& Schreuder, 2009; Kniveton, 2004). This especially applies to employees in managerial positions, since no two managerial career paths are identical. Furthermore, several developmental milestones shape the human capital and motivation of these employees and thereby influence their perception of success in the workplace (Eddleston, Baldridge \& Veiga, 2004). Sturges (1999) also postulates that the type of position a manager occupies may determine that person's perception of career success. This means that the managerial position as such does not determine how success is defined and attained.

Colakoglu (2011) reasons that the pursuit of boundaryless careers can support but also hinder individuals' career success. In a study done by McDonald and Hite (2008), young professionals indicate that to them career success is more complex than just reaching the highest rank on a particular ladder; it is influenced by various factors. By considering management employees' perceptions of the factors that influence their career success, organisations can try to establish these favourable working conditions, as well as constructive human resource practices which may help them to retain the top talent amongst South Africa's managers.

\section{Research purpose and objectives}

Extensive international research is available on factors influencing career success (for an overview see $\mathrm{Ng}$, Eby, Sorensen \& Feldman, 2005). Nevertheless, there seems to be a paucity of research into factors influencing career success, especially within the South African work setting. In an attempt to assist South African organisations with the retention of topclass employees, the purpose of this study was to identify specific factors that influence the career success of managers within the South African context, thereby helping to focus companies' retention strategies. The overall research question that guided this study was: What factors (given the South African context) influence the career success of managers in South Africa?

\section{Background of career success}

Career success has traditionally been viewed from the perspective of the organisation. According to this view, the employee's attainment of career success implied the achievement of certain organisational goals. Or, alternatively for the individual, career success implied lifetime employment in one organisation or a steady climb up the corporate ladder (Adamson, Doherty \& Viney, 1998). However, according to Eby, Butts and Lockwood (2003), in the light of the changing career environment this tendency can no longer be guaranteed.

There is a shift in current literature on the career environment, according to which traditional careers are being replaced by more boundary-less careers. The latter are relatively unpredictable, disorderly and frequently include mobility across organisations (Arthur, Inkson \& Pringle, 1999; Arthur, Khapova \& Wilderdom, 2005). Since careers are changing more, researchers agree that they have to start building new models to understand the changing nature of careers (Adamson et al., 1998; Eby et al., 2003; Feldman \& Ng, 2007; Heslin, 2005; Hite \& McDonald, 2008; Mahler, 2008). This has led researchers to try and pinpoint the individual and organisational variables that play a role in facilitating employees' perceived attainment of career success (Heslin, 2003). There is an increase in literature covering the changing career environment (Adamson et al., 1998; Arthur et al., 2005; Feldman \& Ng, 2007; Hite \& McDonald, 2008; Park, 2010). In the light of this new knowledge, researchers came to realise that career success can best be understood as consisting of both objective and subjective components (Gunz \& Heslin, 2005; Heslin, 2005; Langford, 2000). According to Judge, Cable, Boudreau and Bretz (1995), career success can be defined as the objective or subjective perception of accomplishments by individuals during their work experiences, which suggests an objective and a subjective dimension.

\section{Objective and subjective career success}

A more detailed distinction between objective and subjective career success is found in the viewpoint of Arthur et al. (2005). According to them, objective career success is viewed as the external component of career success. This includes the observable, measurable and verifiable achievements of an individual's career situation. Such success may manifest in factors such as pay, promotion and occupational level and status (Heslin, 2003). Subjective career success, on the other hand, is based on the internal components, which involve the individual's personal internal interpretations, perspectives and evaluations of their success in the workplace (Arthur et al., 2005). Given the importance and popularity of career success in academic literature, researchers from diverse disciplines continue to investigate the individual and organisational factors that contribute or predict employees' attainment of career success, in particular the success of those holding managerial positions (Bozionelos, Bozioneles, Kostopoulos \& Polychroniou, 2011; Coetzee \& Schreuder, 2009; Eddleston et al., 2004; Grimland, Vigoda-Godat \& Baruch, 2012; Kirchmeyer, 1998; Langford, 2000; Rasdi, Ismail \& Garavan, 2011; Sturges, 1999; Tu, Forret \& Sullivan, 2006).

\section{Predictors of career success}

Most of the studies that explore the factors influencing career success have been conducted across international boundaries. South African studies that investigate such factors are, however, rather limited. A summary of international and national studies investigating the predictors of career success is shown in Table 1. Where international researchers seem to differ in their categorisation of predictors of career success, South African studies are limited to focusing on women and their career success. Therefore, research reflecting the factors influencing career success within the South African setting seems to be timeous.

\section{Research design Research approach}

This study was undertaken as an exploratory research endeavour to gain insight into the perceived factors that 
TABLE 1a: Summary of South African studies focusing on predictors of career success.

\begin{tabular}{lll}
\hline South African studies & Authors & Focus of the study \\
\hline $2011-2012$ & Riordan \& Louw-Potgieter (2011) & Career success of women academics in South Africa \\
$2009-2010$ & Coetzee, Bergh \& Schreuder (2010) & Career orientations on subjective work experiences \\
& Coetzee \& Schreuder (2009) & Psychological career resources as predictors of working adults' career anchors \\
Before 2009 & Riordan (2007) & Psychological factors in career situations as antecedents of women academics' career success \\
& Rowe \& Crafford (2003) & Barriers professional women face in career advancement \\
\hline
\end{tabular}

TABLE 1b: Summary of international studies focusing on predictors of career success

\begin{tabular}{|c|c|c|}
\hline International studies & Authors & Classification or categorisation of predictors investigated \\
\hline \multirow[t]{5}{*}{ 2011-2012 } & Verbruggen (2012) & Psychological mobility (e.g. boundary-less mind-set and mobility preference) \\
\hline & Grimland, Vigoda-Godat \& Baruch (2012) & Social capital, perceptions of organisational policies, protean career attitudes \\
\hline & Rasdi, Ismail \& Garavan (2011) & Individual, structural and demographic variables \\
\hline & Enache, Sallan, Simo \& Fernandez. (2011) & Protean and boundary-less career attitudes and gender \\
\hline & Colakoglu (2011) & Career boundaryless-ness (e.g. career competencies, career autonomy, career insecurity) \\
\hline 2009-2010 & Park (2010) & $\begin{array}{l}\text { Calling work orientation (e.g. meaning of work), individual career enhancement strategy (e.g. consultation), } \\
\text { organisational learning climate (e.g. HRM environment) }\end{array}$ \\
\hline \multirow[t]{4}{*}{ Before 2009} & $\begin{array}{l}\text { Ng, Eby, Sorensen \& Feldman (2005) } \\
\text { (meta-analysis) }\end{array}$ & $\begin{array}{l}\text { Human capital (e.g. job tenure), organisational sponsorship (e.g. career sponsorships and training), socio- } \\
\text { demographic status (e.g. gender, marital status), stable individual difference (e.g. personality factors) }\end{array}$ \\
\hline & Judge, Cable, Boudreau \& Bretz (2005) & $\begin{array}{l}\text { Demographic (e.g. age), human capital (e.g. education), motivational (e.g. ambition), organisational } \\
\text { characteristics (e.g. industry/sector) }\end{array}$ \\
\hline & Eddleston, Baldridge \& Veiga (2004) & Individual differences (e.g. education, career impatience), career-related beliefs (e.g. marketability) \\
\hline & Eby, Butts \& Lockwood (2003) & $\begin{array}{l}\text { 'Knowing why' category (e.g. career insight), 'knowing whom' category (e.g. mentor), 'knowing how' } \\
\text { category (e.g. job-related and career-related skills and knowledge) }\end{array}$ \\
\hline
\end{tabular}

influence career success of managers in South Africa. A qualitative explorative approach was used in this research. According to this approach the researcher aims to describe the lived experiences of participants as accurately as possible, without being influenced by any pre-given framework (Thomas, 2004). This is done by collecting more situational information, and determining the meanings and purposes that individuals ascribe to their actions (Guba \& Lincoln, 1994).

\section{Research strategy}

In this exploratory case study, employees were interviewed who are employed at various managerial levels within two independent international financial institutions in South Africa. Exploratory case studies aim to provide familiarity with a phenomenon by taking a good look at it, and to generate data that will provide insight into the phenomenon (Rule \& John, 2011).

\section{Research method}

\section{Research setting}

The research setting and physical environment is crucial as it can affect the outcome of the research (King \& Horrocks, 2010; Terre Blanche, Durrheim \& Painter, 2006). Therefore, great care was taken to ensure the comfort, privacy and quietness of the interview location within the organisations that participated in the research.

\section{Entree and establishing researcher roles}

Initially, the researcher clarified the objectives and procedures with the key decision-makers within the selected organisations. That was done after permission was granted to enter the research field and to conduct the study. A specific employee (also referred to as a 'gatekeeper') was identified by the institutions and designated to help the researcher with logistical aspects of the research and to negotiate research relationships (e.g. communicating the research opportunity to employees, identifying possible participants and scheduling the interviews) (De Vos, Strydom, Fouche \& Delport, 2011; Maxwell, 2005). To ensure that quality data was collected (Boyce \& Neale, 2006), the researcher was trained appropriately in interviewing techniques (Neuman, 2003). Reflexivity in quality research is also of utmost importance (Boyce \& Neale, 2006; Terre Blanche et al., 2006). Therefore, the researcher made time after each interview to reflect on the interview and recorded these reflections as part of the field notes.

\section{Participants and sampling}

A purposive, voluntary non-probability sample of 24 managers was included in this study. These managers were selected from two separate independent, internationally recognised financial institutions. The inclusion criteria implemented were based on those of objective career success (Ng et al., 2005). Such criteria imply that participants occupy a management position or higher and have between five and ten years managerial experience. Employees who complied with the inclusion criteria and were willing to participate were included in the sample. The number of participants in the sample was determined by data saturation (Burns \& Grove, 1997).

The sample contained mostly English-speaking (58.30\%) male managers (54.20\%) between the ages of 35 and 55 years $(66.60 \%)$ and was representative of various management levels (i.e. director level 29.20\%, executive level 20.80\%, middle management level $20.80 \%$ and senior management level $16.80 \%$ ). Only a small number of the participants were employed on partner base $(4.20 \%)$, or occupied other positions. The remaining categories were associate managers (4.20\%) and associate directors (4.20\%). In terms 
of years of experience, $37.50 \%$ of the managers had between five and ten years, and $20.80 \%$ had between 10 and 15 total years of experience. Interestingly, $75 \%$ of the participants indicated that they had been working for longer than one year, but for less than five years in the same position, whereas only $8 \%$ participants of the sample had remained for more than 10 years in their current work position.

\section{Data collection methods}

Data was collected in the research by means of semi-structured individual interviews. After giving informed consent, the participants were asked three standard successive questions. The first question, which served as background to the study, was 'Do you feel that you experience success in your career?' Whether interviewees answered yes or no, they were asked to explain their answer. Then they were asked the second question: 'What aspects or factors do you feel influence your career success?' The third question followed: 'What aspects have contributed to you reaching your career goals?' The aim was to encourage participants to elaborate on their thoughts, feelings, perspectives and experiences.

\section{Recording of data}

Interviews were recorded digitally and comprehensive field notes were taken (also referred to as 'observation notes'). Field notes provide a written account of the researcher's experience through sight, hearing and thought during the interview process and can be categorised as methodology notes, personal notes and theoretical notes (Hesse-Biber \& Leavy, 2004). All of the verbatim transcripts and field notes were prepared for data analysis. In order to maintain confidentially throughout the process, the interviews, field notes and transcriptions were labelled by a coding system exclusively known to the researcher involved. The anonymity of the audio files' content, as well as of the transcription and field notes, was upheld for this purpose and all the data was stored in a secure place.

\section{Data analyses}

The obtained data was analysed using content analysis. This entails a systematic technique that gathers and compresses large bodies of text into specific and identifiable content categories, which can be analysed (Hesse-Biber \& Leavy, 2004). Content analysis focuses on content and contextual meaning of the text. In this sense the analysed data helps the researcher to draw replicable and valid inferences (Hsieh \& Shannon, 2005). As a starting point, the researcher read the interviews several times thoroughly, in order to get a larger picture of the content. Thereafter the responses of the participants (comprising the actual text) were categorised into meaningful units of sentences or paragraphs. These units were categorised or sorted into two major themes. Careful analysis of these themes resulted in the deduction of various smaller, comparable sub-themes. The researcher and the cocoder discussed the analysis and agreed on two themes and the sub-themes that were deduced. Another aspect of data analysis was to work through the field notes taken by the researcher (De Vos et al., 2011). Field notes documented in this research revealed neither noteworthy new meaning, nor contrasting evidence or findings.

\section{Strategies to ensure quality data}

Principles with respect to quality data were upheld in this research. These principles include accuracy, context and density of descriptions, usefulness and reflexivity (Richards, 2009). More specifically, the following methods were employed: (1) pre-pilot interview training, (2) clear and careful descriptions of each stage of the research, (3) comprehensive field notes taken after each interview, (4) an independent co-coder, (5) critical open discussions between the researcher and co-coder on the process and the results of the data analysis, (6) feedback sessions with the management of the participating organisations on the overall findings of the research and (7) clarification and confirmation of themes with some participants.

According to Weber (1990), one of the major concerns about content analysis is the bias of the rater; hence, he suggests a coding scheme for data analysis. Such a coding scheme was developed and discussed between the researcher and an independent co-coder. According to Hesse-Biber and Leavy (2004), a co-coder's role is to contribute to the reliability and validity of the data. The overall quality of the data could be enhanced by collaboration between the co-coder and the researcher, which helped to identify and establish the relevant themes and sub-themes. This was done during an open discussion between the researcher and co-coder in which the themes and sub-themes were evaluated.

\section{Reporting}

In the subsequent findings section, the two major influential factors and subsequent sub-factors are discussed.

\section{Findings}

Data analysis yielded various factors that contribute to or impede the career success of managerial employees (see Figure 1) and these are discussed below. Table 2 and Table 3 summarise these factors and provide example quotes from the responses.

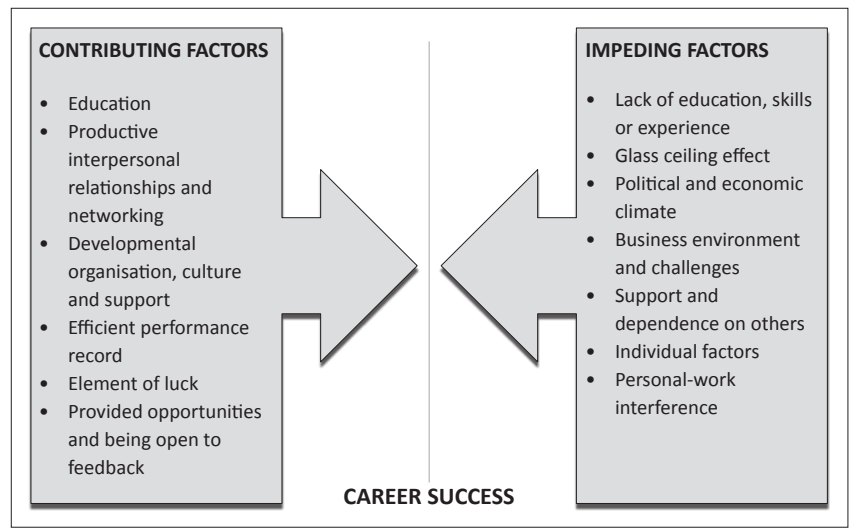

FIGURE 1: Factors contributing to and impeding career success. 


\section{Contributing factors}

Table 2 illustrates specific factors contributing to the success of managers.

From the interviews, it seems that the main contributing factors for success for managers revolve around their interpersonal skills, network relationships and their ability to perform. Interestingly, although having a good educational background is perceived as a contributing factor to success, having a good performance record is crucial. Managers who are known to perform and deliver work of a high standard, are more often perceived as being successful in their careers. Also managers' openness to feedback and constructive criticism for self-development are perceived as contributing to their success:

'If you're focused on a good work output, you know, if you're focused on ensuring that you deliver on what you need to deliver.' (Participant 9B)

'I think I've built good relationships along the way and I haven't burnt bridges or haven't gone into situations where I have disregarded and disrespected people.' (Participant 9B)

Sometimes, management employees may succeed in their careers because they found themselves 'at the right place at the right time'. For example, someone may enter an organisation during a growth phase and also receive the right opportunities at the appropriate times, such as promotions or opportunities for international exposure. Also, being employed within an organisation where shared knowledge and skills are part of a working culture seems to contribute to success. A mind-set of knowledge sharing, skills development and career development present within the organisation is crucial:

'It's that exposure, I don't know if it was all planned but I was lucky in that sense that I had these opportunities to get the right exposure up to this point.' (Participant 8B)

After further scrutiny of these contributing factors, it seems that some factors are aspects that managers can address or attend to in order to enhance their perceived career success. These factors almost suggest that managers (and other employees) can do something in order to contribute to their success. For example, managers can obtain an excellent education, can perform, can enjoy productive relationships and networks and can be open to feedback, all of which may contribute to their success.

On the other hand, some of the contributing factors are not always aspects to which managers can attend; these are perceived as external factors contributing to their success. These include factors such as the element of luck, provided opportunities, working within an organisation that espouses a developmental culture of sharing knowledge, as well as being supported by managers and colleagues. These are factors that organisations can look at in order

TABLE 2: Summary of factors perceived to contribute to career success

\begin{tabular}{|c|c|c|}
\hline Factor & Meaning or explanation & Example quotes \\
\hline Education & $\begin{array}{l}\text { Possessing certain levels of education or a specific qualification; the } \\
\text { appropriate educational background; applying the theoretical foundation } \\
\text { provided by education. }\end{array}$ & $\begin{array}{l}\text { 'So I'll say your gateways are your education, so if you don't have a good } \\
\text { education, you don't have the background, you don't get into, nobody } \\
\text { even considers your CV.' (Participant 2B) }\end{array}$ \\
\hline $\begin{array}{l}\text { Interacting with } \\
\text { successful individuals }\end{array}$ & $\begin{array}{l}\text { Interacting with successful individuals to measure oneself against; } \\
\text { displaying and emulating the attributes reflected by successful individuals; } \\
\text { being mentored or guided by successful individuals. }\end{array}$ & $\begin{array}{l}\text { 'Good leadership, you know people with insight that can also assist you } \\
\text { and coach you as you go along.' (Participant } 8 \mathrm{~A} \text { ) } \\
\text { 'You've always got somebody that you measure up against, somebody } \\
\text { involved in the company that you see is achieving success or displaying } \\
\text { you know, the, attributes, and you're using them as role models, and as } \\
\text { guidance.' (Participant 10A) }\end{array}$ \\
\hline Being open to feedback & $\begin{array}{l}\text { Being open to feedback and constructive criticism for self-development; } \\
\text { receiving feedback on key performance indicators (KPIs); receiving good } \\
\text { performance appraisals. }\end{array}$ & $\begin{array}{l}\text { 'To have someone like that and that someone that's gonna tell you } \\
\text { "hey you're stuffing up" cause it's good to have that sort of constructive } \\
\text { criticism.' (Participant 1A) }\end{array}$ \\
\hline $\begin{array}{l}\text { Having an efficient } \\
\text { performance record }\end{array}$ & $\begin{array}{l}\text { Delivering work of a high standard; being recognised for good work and } \\
\text { for delivering above and beyond promises made. }\end{array}$ & $\begin{array}{l}\text { 'So having an education is not end door and beyond, it's just a gateway, } \\
\text { thereafter it's your delivery, you have to deliver as well, so if you promise } \\
\text { something you have to deliver and if you're delivering consistently, nobody } \\
\text { has to follow up.' (Participant 2B) }\end{array}$ \\
\hline Element of luck & $\begin{array}{l}\text { Perception of being 'at the right place at the right time'; fortunate in } \\
\text { terms of joining a growing organisation; fortunate with being afforded the } \\
\text { right opportunities at the right time. }\end{array}$ & $\begin{array}{l}\text { 'I'll add that timing plays such a key role, so, it's also a matter of luck: being } \\
\text { at the right place at the right time, because as organisations grow just like } \\
\text { a new product. There is an introductory phase and then rapid growth and } \\
\text { if you happen to be part of that, then you can benefit from the success.' } \\
\text { (Participant 1B) }\end{array}$ \\
\hline Provided opportunities & $\begin{array}{l}\text { Being given opportunities and challenges to test and prove capability; } \\
\text { provided opportunities for personal and career growth; afforded } \\
\text { opportunities for hierarchical and lateral progression; gaining } \\
\text { international exposure. }\end{array}$ & $\begin{array}{l}\text { 'It is also the learning opportunities that I was also given.' (Participant 6A) } \\
\text { 'So I think I have been quite lucky and successful to do what I have } \\
\text { achieved so far, but I think that came, because I have overseas experience.' } \\
\text { (Participant 5A) }\end{array}$ \\
\hline $\begin{array}{l}\text { Support from managers } \\
\text { and colleagues }\end{array}$ & $\begin{array}{l}\text { Receiving support from managers and colleagues for both work and } \\
\text { personal issues; having a supportive network at work; receiving executive } \\
\text { sponsorship from key decision-makers within the organisation. }\end{array}$ & $\begin{array}{l}\text { 'I think having a supportive team, so if you have a boss that supports } \\
\text { you, who is available to listen to you when you have a problem, then it's } \\
\text { definitely a big thing in terms of career success.' (Participant } 2 A \text { ) } \\
\text { 'To have someone to develop you and to listen not just professionally, but } \\
\text { also if you have a personal issue, hmm then that really assists in terms of } \\
\text { career growing.' (Participant 2A) }\end{array}$ \\
\hline $\begin{array}{l}\text { A developmental } \\
\text { organisational culture }\end{array}$ & $\begin{array}{l}\text { Working in an organisational culture of shared knowledge and skills } \\
\text { development; working for an organisation with a reputable organisational } \\
\text { culture that is conducive to the development of a career. }\end{array}$ & $\begin{array}{l}\text { 'I think that the major investment is having people within the firm to } \\
\text { develop you; who want to share with you their knowledge; who are open } \\
\text { to you challenging them on certain things and you know who are also open } \\
\text { to you messing up and learning from those mistakes.' (Participant 1A) }\end{array}$ \\
\hline
\end{tabular}


to ensure that employees and managers are successful in their careers.

Opposing these contributing factors, factors hindering or impeding the success of management employees were also extracted from the interviews.

\section{Impeding factors}

Specific factors as listed in Table 3 seem to hinder or impede career success for managers.

Several factors that impede managers' career success (see Table 3) seem to be related to the organisation as well as its responsibility and culture. For example, some managers explained how they had reached a ceiling in their career: the more such a manager progresses hierarchically in the organisation, the fewer opportunities and positions are available to them. There seems to be this tendency: once someone has reached their peak in the organisation, such a person may get stuck in that position. This may inhibit any further progress, and consequently career success.

Organisations sometimes also force managers in one direction within the organisation, which is completely different from the direction they themselves envisage for their career path as managers. Managers sometimes feel they are not given enough opportunities to grow in their careers (this implies not only opportunities for hierarchical progression). Lack of support from the organisation was also mentioned as a significant factor hindering career success, especially when managers need the organisation to 'buy into' their career, in terms of new ideas, plans and strategies. If not, the growth and development of their career will be limited or even non-existent.

TABLE 3: Summary of factors perceived to impede career success

\section{Factor} Meaning or explanation

Lack of education or job Below minimum level of qualification; failure to pass a board examination experience crucial to role requirements or certain positions; lack of exposure needed for specific positions.

Reaching a ceiling in one's In terms of hierarchy one reaches a ceiling; limited opportunities as one caree progress in the hierarchy; fixed positions in the organisation and the need for a vacancy before one can move up the ladder.

Glass ceiling for women A glass ceiling still exists for women in the modern workplace; women are constantly struggling to prove their worth; they feel prevented from pursuing a career actively.

Lack of skills Lack of competence, ability and interpersonal skills.

Dependence on others

Own performance dependent on other employees' decisions, feedback and performance; success of plans and ideas depend on whether senio managers in the organisation buy into new plans and ideas; the nature of the relationship with employees are one of dependency (e.g. conflict in relationships can complicate things).

Challenges in business Lack of direction and structure within the business environment; environment confusion around organisational structure and culture; ineffective management or leadership; changes in political hierarchy, leadership or business models; competing in an extremely competitive and complex business environment; having strict budgets that limit opportunities for development.

Nature of political and economic climate

The transitions locally and in the world, especially political transition (e.g. transition from apartheid to democracy in South Africa); challenge related to certain political eras (e.g. lack of educational and career opportunities during apartheid era); changes in economic climate (e.g. recession, Eurozone crisis); political influences in the economic climate (e.g. transformation, BEE, affirmative action, uprisings and strikes)

Misalignment of personal Personal goals and values clash with organisational goals and values; goals and values with organisational goals and values

Lack of support from organisation a conflicting value systems between employee and organisation; a conflicting value systems between employee and organisation;
organisation pushes one in a direction that is unwanted and which one organisation pushes one
did not intend to follow.

Lack of organisational support in work and personal issues; lack of support and involvement in career planning and development; insufficien resources for professional development.

Personal-work life interference (PWI)

Personal life interfering with work; having children and wanting to work in a more flexible manner; personal circumstances or issues interfering with work responsibilities; inability to balance work duties and family or personal duties; interference of personal problems with work, impeding job performance.

Individual factors Mind-set and attitude towards career success; lack of motivation; insufficient effort or performance; lack of self-insight and selfdevelopment; unwillingness to take responsibility for own career development.

\section{Example quotes}

'You know if you don't have a certain level of education, it just doesn't give you access to the game, so you're binding yourself if you haven't invested in getting yourself educated.' (Participant 1B)

'I think within this organisation, there's only so far you can go.' (Participant $4 \mathrm{~A})$

'You sort of reach a ceiling where you think, "Well I'm not going to go anywhere beyond here, unless $X, Y, Z$ retire or leave". Sometimes you get to a point and you can't move any further until the next person moves on and then you can move into their position.' (Participant 10A)

'Also there's a glass ceiling for a woman, it is a boys' club so you needed to go to the right schools.' (Participant 2B)

'So there's a glass ceiling there, so you constantly fight to prove to people. You're constantly proving and your constantly fighting, so you have to work twice as hard as your peer just to prove that you can do it as well.' (Participant 2B)

'Things that hamper people are also the lack of skill, competence to be able to get to that next level.' (Participant 7B)

'If you don't deliver once you start to get a blemish and then people start to mistrust you.' (Participant 2B)

'And you know, it's a classic one of if you're too valuable in my space, I'm not gonna tell people about it, because then I'm gonna lose you.' (Participant 8B)

'Because something that really hinders success is doing something in a silo and believing that other people are in agreement with you. (Participant 2A)

I think very often, you know, the external environment, the market, clients, you know, financial distress, eurozone crisis, all those things are easy, easily to divert the energy, in terms of trying to achieve what you want to set out.' (Participant 12B)

'If you have staff complaining about they don't know what to do, and the manager also is not clued up with what needs to be done up there. (Participant 3A)

'Things are different now, because of the recession and the way the world has changed, I mean look if you wanted to go for a position, external to the company you are working for and it, it would say that it's an affirmative action position only. Then you can't apply for it, because you're White. So we have a lot of positions like that here, and mainly the more junior ones, where it's affirmative action only, so you can't even apply if you're White, the other one's are preference will be given to an employment equity candidate and then you're already on the back footing, so it does hinde success.' (Participant 5A)

'Well, I don't really think specifically that I wasn't ready, it's just that they're pushing you in this direction.' (Participant 6A)

'So you can be placed into a role and if it's not the right thing for you, you will not be able to be successful in your career.' (Participant 7B)

'I mean you can stand out and you can bring ideas to the table each and every day, if the company doesn't except or, not inherit, or adopt those ideas and concepts, you gonna get nowhere as well.' (Participant 10A)

'I think family issues, because a lot of us have and then you've got a baby but I never gave up I've always tried to find a balance, you've got to find a balance.' (Participant 3A)

'Significantly, I think I would be very, in a different place if I hadn't had a child, and wanting to work flexibly and to have the best of both worlds.' (Participant 7A)

'Most people unfortunately sit back and they say, and they complain and they moan and the groan about things, but you know they do nothing to actually change their lot in life.' (Participant 4B)

I have a personal belief that a lot of people have the most incredible capacity; however, it's limited by their own state of mind as to whether they really wanna do something and whether they believe in them or not.' (Participant 4B) 
Some managers also pointed out that they perceived the influence of political issues, such as the legacy of apartheid, as an obstacle to achieving success in their careers. Such managers perceived the transition from the apartheid era to the democratic era, particularly in terms of BEE and affirmative action, as an obstacle to their career. The following quote reflects this observation:

'I think it definitely restricts career success, because when you have a look at it from any angle on all the different seven levels of transformation, you're looking at your percentages of what you've got to have at the different levels. For example, if you have too many White people at a certain level, and that's the level you want to aspire to get to, you're just going to have to sit back and wait until the percentages are sorted out. So that can hinder you by however long it takes to come right.' (Participant 5A)

Although it seems that organisations and external aspects impede managers' success considerably, participants did indicate their own shortfalls. According to the participants in this sample, several internal factors do impact negatively on the development of their careers. These include their own lack of motivation and limited self-insight, as well as lack of education or skills.

\section{Discussion \\ Outline of the findings}

In an era focused on attracting, developing and retaining a knowledgeable workforce, the pursuit of boundary-less careers can support but also hinder individuals' career success (Colakoglu, 2011). When reviewing the research question posed in this study (what factors influence the career success of management employees?), two types of factors were forthcoming: contributing factors and impeding factors. Contributing factors entailed mostly factors that enhance, improve or increase career success, whereas impeding factors were those factors that hinder, obstruct, hamper or delay the attainment of career success.

Firstly, contributing factors were identified that are further disaggregated into:

- 'Can do' factors such as education, interpersonal skills, network relationships and performance.

- External factors such as element of luck, opportunities provided, developmental culture of sharing knowledge and supportive managers and colleagues.

Secondly, impeding factors which are disaggregated into:

- Organisational or business-related factors such as the glass-ceiling effect, economic climate, business environment and lack of support.

- Individual factors such as personal attitudes, lack of skills and education, personal-work life interference.

\section{Relating main findings to literature}

Of the contributing factors managers mentioned, several are in accordance with international literature that is focused on predictors of objective and subjective career success (i.e. education, networking interacting with successful individuals and performance). In previous studies by Eddleston et al. (2004) and Nabi (1999), education and hard work were found to be significant predictors of objective career success. Although networking and consultation with mentors and skills development were not related significantly to objective career success in the Eddleston et al. (2004) and Nabi (1999) studies, managers in the sample of this study did indicate that interaction with successful individuals did contribute to their career success. This might be related to the specific South African context with its mandatory regulations and legislations (such as BEE and employment equity legislation). It might be that managers feel that this background almost necessitates the use of mentors and interaction with successful individuals in order to succeed. This is also in line with findings of McDonald and Hite (2008). Managers elaborated on this factor by explaining that they specifically attempt to display the attributes or characteristics of successful individuals, which contributes to their perceived success. Continuous learning and being part of an organisation that provides support for learning and development is also known as a significant predictor of subjective career success (Maurer \& Chapman, 2013; Park, 2010). This corresponds with managers' view in this study that a developmental organisational culture with shared knowledge and skills development is perceived as crucial for their career success. This is not surprising since South African organisations do focus on skills development, via the implementation of workplace skills plans and the opportunity of the organisations to obtain funding from the government for skills development. Given this opportunity, organisations in South Africa have an added advantage of establishing a developmental organisational culture, which could enhance the career success of individuals, as explained in the present study.

The contributing factors identified in this study relate to a large degree to the interpretation of the predictors of 'knowing why', 'knowing whom' and 'knowing how' about career success, as they are conceptualised internationally (Eby et al., 2003). Contributing factors such as being open to feedback may correspond with the 'knowing why' predictors (e.g. openness to experience and career insight); interaction with successful individuals may correspond with the 'knowing whom' predictors (e.g. networking) and a developmental organisational culture may correspond with the 'knowing how' predictors (e.g. engaging in continuous learning). Although the majority of the contributing factors that emerged from the present study are found in international literature, additional new unique impeding factors also emerged. The element of luck, which participants explained as 'being at the right place at the right time', as well as the maintenance of productive interpersonal relationships with others within the work environment are both aspects that were not noted in previous studies.

When considering the impeding factors identified in this study, interestingly, similar factors contributing to career 
success were also found amongst those factors reported to impede career success. For instance having an appropriate educational background and holding a good performance record are seen as beneficial to employees' career success, but in some instances lacking certain levels of qualification or lacking exposure or experience are factors that impede their success. These impediments, taken together with the lack of specific competencies or skills, as well as lack of support from the organisation, certainly could inhibit managers' career success.

Impeding factors identified through this research are in accordance with Supangco (2011), who argued that career success depends on the actions of both the organisation and the individual. Findings in the present study suggest that the majority of factors impeding the career success of managers in South Africa are related to the organisational environment in the work context of South Africa. Factors mentioned are political influences in the economic climate, lack of skills, business environment challenges and glass-ceiling effects. These factors are plausible given the impact of South African issues and regulations on business performance in South Africa, as reported by Kruger (2011) and Abbott, Goosen and Coetzee (2013). The present study has highlighted certain South African issues mentioned in these previous studies (e.g. BEE, education or skills development, legislation in general, politics, economy, inequality, employment equity, labour relations and transformation). It was found that these issues currently not only influence businesses in South Africa but also impact on the career success of managers.

Together with the work setting impeding the career success of managers, individual factors also seem to play a role. Managers did mention the lack of motivation and self-insight. Some managers are unwilling to take responsibility for their own actions or careers as aspects that may inhibit their career success. Although some studies have investigated the role of personality or personal attributes in career success (Seibert \& Kraimer, 2001; Wu, Foo \& Turban, 2008), studies investigating specific behaviours that employees exhibit and how those influences their career success is lacking.

\section{Practical implications}

It is imperative that South African organisations establish favourable working conditions and human resource practices that may help with the retention of managers. Therefore, such organisations should attempt to enhance or emphasise the importance of the factors contributing to career success, whilst trying to reduce the effect of factors impeding such success (e.g. having informative workshops on these factors with employees on a regular basis). Findings in this study suggest that both the individual and organisation can implement strategies to ensure career success and thereby help to retain the top talent in organisations. Overall, in terms of the contributing factors, individuals (employees) should focus on the 'can do' factors, where their efforts and attention could contribute to their success. Although organisations should emphasise and encourage such aspects, employees should take responsibility themselves and focus on establishing networks, educating themselves and performing within the organisation. Organisations should emphasise the need for efficient performance amongst employees and encourage them to deliver above and beyond the promises they have made in terms of performance.

On the other hand, the organisations should also help employees by 'managing' the external contributing factors more effectively. Organisations need to foster a developmental organisational culture with shared knowledge and development of skills by encouraging shared knowledge and continuous learning. They should support individuals' actions to require these abilities, by providing opportunities for further studies and developmental programmes. As such, organisations are responsible for creating working environments that are conducive to career development (McDonald \& Hite, 2008).

When considering the impeding factors, again the focus is on the organisation and the individual. Employees need to be more informed about their personal attributes that may influence their perceived attainment of career success. In the literature, a vast number of sources are available that deal with specific personality attributes related to career success (Ballout, 2009; Boudreau, Boswell \& Judge, 2001; Seibert \& Kraimer, 2001). Eby et al. (2003) also emphasise the importance of individuals managing their own careers, rather than expecting their employer to manage it for them. Although employees should understand that it is their responsibility to manage their careers, the present findings suggest that organisations should also understand that managers' careers in South Africa are to a large extent influenced by external organisational or business-related factors, for example legislation and regulations for BEE. South African organisations should investigate strategies that specifically will address those aspects that seemingly are impeding the career success of managers. Future research studies should explore influential factors in more depth, specifically by focusing on South African issues, which do not only influence the performance of the business but also the career success of individuals.

Another impeding factor mentioned was managers' dependence on other employees (i.e. in terms of decisions, feedback and performance). One way to diminish this problem is to point out this type of relationship to employees and managers alike. This could be done by means of specific interventions aimed at effective group work, interpersonal skills training or efficient conflict management. It is important to counter the possibility of misaligning personal goals and values with organisational goals and values. Kuijpers and Scheerens (2006) emphasise this notion of career competencies in the modern career. Therefore, employees should be encouraged to explore or identify organisational values at the beginning of their employment within the organisation concerned. This implies a new focus 
for organisations regarding their induction programmes for new employees. These programmes should clearly indicate the organisation's values and its expectations of employees who work within such an environment (Järlström, 2000; Jiang, Klein \& Balloun, 2001; Schein, 1996).

Unrealistic work aspirations could discourage the performance of management employees. Therefore, regular discussions on career progress and career path are suggested. During these discussions employees can be provided the opportunity to communicate their career needs and career plans and share the progress they have made to date (Schein, 1990; 1996).

\section{Limitations of the study}

Notwithstanding the rich in-depth contributions of this study to help understand the dynamics of factors that influence career success, some important limitations are worth mentioning. One such limitation is that the managers in this sample were selected from financial institutions. Thus, the factors recognised and explored in this study could possibly be only representative of the particular organisations and their cultures. However, the participants' responses may still be typical of what managers in South African workplaces experience, thereby allowing for the transferability of the findings (Appleton, 1995; Terre Blanche et al., 2006). Considering cross-cultural differences in terms of the conceptualisation and experience of career success (Ng et al., 2005), another limitation is that the sample was not representative of the different cultural groups' diverse languages: the majority of the sample was English-speaking. Future studies incorporating more participants from different cultural or language groups might reveal additional perspectives on career success.

\section{Conclusion}

In order to retain top talent in organisations, the investigation of factors influencing the career success of managers is crucial. Although the present findings suggest that both the individual factors and organisational factors can contribute to or impede the career success of managers, the role of the organisational environment in the work environment of South Africa is considerable.

\section{Acknowledgements}

The material described in this article is based on work supported by the National Research Foundation (NRF) under the reference number TTK20110823000025405. Any opinions, findings and conclusions or recommendations expressed in this material are those of the authors and therefore the NRF does not accept any liability in this regard.

In addition: the author wishes to acknowledge and thank Ms $\mathrm{S}$. Visagie for conducting the interviews and assisting with the data analysis on this project.

\section{Competing interests}

The author declares that she has no financial or personal relationship(s) that may have inappropriately influenced her in writing this article.

\section{References}

Abbott, P., Goosen, X., \& Coetzee, J. (2013). The human resource function contribution to human development in South Africa. SA Journal of Human Resource Management, 11, 1-14. http://dx.doi.org/10.4102/sajhrm.v11i1.408

Adamson, S.J., Doherty, N., \& Viney, C. (1998). The meanings of career revisited: Implications for theory and practice. British Journal of Management, 9(4), 251-259. http://dx.doi.org/10.1111/1467-8551.00096

Appleton, J.V. (1995). Analysing qualitative interview data: Addressing issues of validity and reliability. Journal of Advanced Nursing, 22(1), 278-308.

Arthur, M.B., Inkson, D., \& Pringle, J. (1999). The new careers: Individual action and economic change. London, UK: Sage.

Arthur, M.B., Khapova, S.N., \& Wilderdom, C.P.M. (2005). Career success in a boundaryless career world. Journal of Organisational Behaviour, 26, 177-202. http:// dx.doi.org/10.1002/job.290

Ballout, H.I. (2009). Career commitment and career success: Moderating role of self-efficacy. Career Development International, 14(7), 655-670. http://dx.doi. org/10.1108/13620430911005708

Boudreau, J.W., Boswell, W.R., \& Judge, T.A. (2001). Effects of personality on executive career success in the United States and Europe. Journal of Vocational Behaviour, 58, 53-81. http://dx.doi.org/10.1006/jvbe.2000.1755

Boyce, C., \& Neale, P. 2006. Conducting in-depth interviews: A guide for designing and conducting in-depth interviews for evaluation input. Retrieved June, 2012, from $\mathrm{http} / / /$ www.pathfind.org/site/DocServer/m e tool series indepth interviews. pdf?doclD=6301

Bozionelos, N., Bozionelos, G., Kostopoulos, K., \& Polychroniou, P. (2011). How providing mentoring relates to career success and organisational commitment. A study in the general managerial population. Career Development International, 16(5), 446-468. http://dx.doi.org/10.1108/13620431111167760

Burns, N., \& Grove, S.K. (1997). The practice of nursing research: Conduct, critique and utilization. (3rd edn.). Philadelphia, PA: WB Saunders. http://dx.doi.org/10.12968/ pnur.1997.8.14.30

Coetzee, M., Bergh, Z., \& Schreuder, D. (2010). The influence of career orientations on subjective work experiences. South African Journal of Industrial Psychology, $8(1), 1-13$.

Coetzee, M., \& Gunz, M. (2012). Careers and retention of staff in the 21st century world of work: Introduction to special edition. SA Journal of Human Resource Management, 10(2), 1-4. http://dx.doi.org/10.4102/sajhrm.v10i2.505

Coetzee, M., \& Schreuder, D. (2009). Psychological career resources as predictors of working adults' career anchors: An exploratory study. South African Journal of Industrial Psychology, 35(1), 1-11.

Colakoglu, S.N. (2011). The impact of career boundarylessness on subjective caree success: The role of career competencies, career autonomy, and career insecurity. Journal of Vocational Behavior, 79(1), 47-59. http://dx.doi.org/10.1016/j. jvb.2010.09.011

De Vos, A.S., Strydom, H., Fouche, C.B., \& Delport, C.S.L. (2011). Research at grass roots: For the social sciences and human service professions. Pretoria, South Africa: Van Schaik Publishers.

Du Preez, J. (2002). The depletion of the human resources pool in South Africa. Acto Commercii, 2, 80-84.

Eby, L.T., Butts, M., \& Lockwood, A. (2003). Predictors of success in the era of the boundaryless career. Journal of Organisational Behaviour, 24, 689-708. http:// dx.doi.org/10.1002/job.214

Eddleston, K.A., Baldridge, D.C., \& Veiga, J.F. (2004). Toward modelling the predictors of managerial career success: Does gender matter? Journal of Managerial Psychology, 19(4), 360-385. http://dx.doi.org/10.1108/02683940410537936

Enache, M., Sallan, J.M., Simo, P., \& Fernandez, V. (2011). Career attitudes and subjective career success: tackling gender differences. Gender in Management: An International Journal, 26(3), 234-250. http://dx.doi. org/10.1108/17542411111130990

Feldman, D.C., \& Ng, T.W.H. (2007). Careers: Embeddedness, mobility and success. Journal of Management, 33(3), 350-377. http://dx.doi. org $/ 10.1177 / 0149206307300815$

Grimland, S., Vigoda-Godat, E., \& Baruch, Y. (2012). Career attitudes and success of managers: The impact of chance event, protean, and traditional careers. The International Journal of Human Resource Management, 23(6), 1074-1094. http:// dx.doi.org/10.1080/09585192.2011.560884

Guba, E.G., \& Lincoln, Y.S. (1994). Competing paradigms in qualitative research. In N.K. Denzin, \& Y.S. Lincoln (Eds.), Handbook of qualitative research (pp. 105-117). Thousand Oaks, CA: Sage.

Gunz, H.P., \& Heslin, P.A. (2005). Reconceptualizing career success. Journal of Organizational Behavior, 26, 105-111.http://dx.doi.org/10.1002/job.300

Heslin, P.A. (2003). Self and other referent criteria of career success. Journal of Career Assessment, 11, 262-286. http://dx.doi.org/10.1177/1069072703254500 
Heslin, P.A. (2005). Conceptualising and evaluating career success. Journal of Organisational Behaviour, 26, 113-136. http://dx.doi.org/10.1002/job.270

Hesse-Biber, S.N., \& Leavy, P. (2004). Approaches to qualitative research: A reader on theory and practice. Oxford, UK: Oxford University Press.

Hite, L.M., \& McDonald, K.S. (2008). A new era for career development and HRD. Advances in Developing Human Resources, 10, 3-7. http://dx.doi. org/10.1177/1523422307310103

Hsieh, H., \& Shannon, S.E. (2005). Three approaches to qualitative content analysis. Qualitative Health Research, 15, 1277-1288. http://dx.doi. org/10.1177/1049732305276687

Järlström, M. (2000). Personality preferences and career expectations of Finnish business students. Career Development International, 5(3), 144-154. http:// dx.doi.org/10.1108/13620430010371919

Jiang, J.J., Klein, G., \& Balloun, J.L. (2001). The joint impact of internal and external career anchors on entry-level IS career satisfaction. Information and Management career anchors on entry-level IS career satisfaction. Information

Judge, T.A., Cable, D.M., Boudreau, J.W., \& Bretz, R.D. (1995). An empirical investigation of the predictors of executive career success. Personnel Psychology, 48(3), 485-519. http://dx.doi.org/10.1111/j.1744-6570.1995.tb01767.x

Kerr-Phillips, B. \& Thomas, A. (2009). Macro and micro challenges for talent retention in South Africa. SA Journal of Human Resource Management, 7(1), 82-91.

King, E.C., \& Horrocks, C. (2010). Interviews in qualitative research. London, UK: Sage Publications Ltd.

Kirchmeyer, C. (1998). Determinants of managerial career success: Evidence and explanation of male/female differences. Journal of Management, 24(6), 673-692. http://dx.doi.org/10.1016/S0149-2063(99)80079-8

Kniveton, B.H., 2004. The influences and motivations on which students base their choice of career. Research in Education, 72, 47-57. http://dx.doi.org/10.7227/ Choice of

Kruger, L.P. (2011). The impact of black economic empowerment (BEE) on South African businesses: Focusing on ten dimensions of business performance. Southern African Business Review, 15(3), 207-233.

Kuijpers, M.A.C.T., \& Scheerens, J. (2006). Career competencies for the modern career. Journal of Career Development, 32(4), 303-319. http://dx.doi. org/10.1177/0894845305283006

Langford, P.H. (2000). Importance of relationship management for the career success of Australian managers. Australian Journal of Psychology, 52(3), 163-169. http:// dx.doi.org/10.1080/00049530008255384

Mahler, E.B. (2008). Defining career success in in the 21st century: A narrative study of intentional work role transitions. Unpublished doctoral dissertation, University of Maryland, USA.

Martins, E.C., \& Martins, N. (2011). The role of organisational factors in combating tacit knowledge loss in organisations. Southern African Business Review, 15, 49-69.

Maurer, T.J., \& Chapman, E.F. (2013). Ten years of career success in relation to individual and situational variables from the employee development literature. Journal of Vocational Behavior, 83, 450-465, http://dx.doi.org/10.1016/j jvb.2013.07.002

Maxwell, J.A. (2005). Qualitative research design: An interactive approach. (2nd edn.) Thousand Oaks, CA: Sage.

McDonald, K.S., \& Hite, L.M. (2008). The next generation of career success: Implications for HRD. Advances in Developing Human Resources, 10, 86-103. http://dx.doi.org/10.1177/1523422307310116

Nabi, G.R. (1999). An investigation into the differential profile of predictors of objective and subjective career success. Career Development International, 4(4), 212-224. http://dx.doi.org/10.1108/13620439910270599
Neuman, W.L. (2003). Social research methods: Qualitative and quantitative approaches. USA: Allyn \& Bacon.

Ng, T.W.H., Eby, L.T., Sorensen, K.L., \& Feldman, D.C. (2005). Predictors of objective and subjective career success: A meta-analysis. Personnel Psychology, 58(2), 367-408. http://dx.doi.org/10.1111/j.1744-6570.2005.00515.x

Park, Y. (2010). The predictors of subjective career success: An empirical study of employee development in a Korean financial company. International Journal of Training and Development, 14(1), 1-15. http://dx.doi.org/10.1111/j.14682419.2009.00337.x

Rasdi, R.M., Ismail, M., \& Garavan, T.N. (2011). Predicting Malaysian managers' objective and subjective career success. The International Journal of Human Resource Management, 22(17), 3528-3549. http://dx.doi.org/10.1080/0958519 2.2011.560878

Richards, L. (2009). Handling qualitative data. (2nd edn.). London, UK: Sage Publications Ltd.

Riordan, S. (2007). Career psychology factors as antecedents of career success of women academics in South Africa. Unpublished doctoral dissertation, University of Cape Town, Cape Town, South Africa.

Riordan, S., \& Louw-Potgieter, J. (2011). Career success of women academics in South Africa. South African Journal of Psychology, 41(2), 157-172. http://dx.doi. org/10.1177/008124631104100205

Rowe, T., \& Crafford, A. (2003). A study of barriers to career advancement for professional women in investment banking. South African Journal of Human Resource Management, 1(2), 21-27.

Rule, P., \& John, V. (2011). Your guide to case study research, Johannesburg, South Africa: Van Schaik Publishers.

Schein, E.H. (1990). Career anchors: Discovering your real values. San Diego, CA Pfeiffer \& Company.

Schein, E.H. (1996). Career anchors revisited. Implications for career development in the 21st century. Academy of Management Executive, 1, 80-88.

Seibert, S.E., \& Kraimer, M.L. (2001). The five-factor model of personality and caree success. Journal of Vocational Behaviour, 58, 1-21. http://dx.doi.org/10.1006/ jvbe.2000.1757

Sturges, J. (1999). What it means to succeed: Personal conceptions of caree success held by male and female managers at different ages. British Journal of Management, 10, 239-252. http://dx.doi.org/10.1111/1467-8551.00130

Supangco, V.T. (2011). Organizational and individual determinants of career success of MBA students. Journal of International Business Research, 10, 113-128.

Terre Blanche, M., Durrheim, K., \& Painter, D. (2006). Research in practice: Applied methods for the social sciences. Cape Town, South Africa: University of Cape Town Press.

Thomas, A.B. (2004). Research skills for management studies. London, UK: Routledge.

Tu, H.S., Forret, M.L., \& Sullivan, S.E. (2006). Careers in a non-western context: An exploratory empirical investigation of factors related to the career success of Chinese managers. Career Development International, 11(7), 580-593. http:// dx.doi.org/10.1108/13620430610713454

Verbruggen, M. (2012). Psychological mobility and career success in the "new" caree climate. Journal of Vocational Behavior, 81, 289-297. http://dx.doi.org/10.1016/j. jvb.2011.10.010

Weber, R.P. (1990). Basic content analysis. Beverly Hills, CA: Sage.

Wu, P., Foo, M., \& Turban, D.B. (2008). The role of personality on relationship closeness, developer assistance, and career success. Journal of Vocational Behavior, 73, 440-448. http://dx.doi.org/10.1016/j.jvb.2008.08.005 